\title{
Die Garisma van die spreek in tale (Glossolalie)
}

\author{
F J VAN ZYL
}

\section{Nuwe Testamentiese gegewens}

\section{Terminologiese onderskeiding}

Die saak van die talespreek word in die Nuwe Testament met die volgende uitdrukkings aangedui:

- lalēin glōssē (glōssais) - om in 'n taal of in tale te spreek: Spreek almal in tale? (I Kor 12:30)

Al sou ek (in) die tale van mense en engele spreek (I Kor 13:1). Hy wat in 'n taal spreek (I Kor 14:2, 4, $5 \mathrm{v} \mathrm{v}$ ).

Want hulle het gehoor hoe dat hulle in tale spreek en God groot maak (Hand 10:46).

En Paulus het hulle die hande opgelê, en die Heilige Gees het op hulle gekom, en hulle het met (in) tale gespreek en geprofeteer (Hand 19:6).

- laleīn glōssais kainais - om in nuwe tale te spreek:

En vir die wat geglo het, sal hierdie tekens volg: in my Naam sal hulle duiwels uitdryf, met nuwe tale sal hulle spreek (Mark 16:17).

- laleīn heterais glōssais - om in ander tale te spreek:

En hulle is almal vervul met die Heilige Gees en het begin spreek in ander tale, soos die Gees aan hulle gegee het om uit te spreek (Hand 2:4).

\section{Nadere bepaling van die Pauliniese gegewens}

- Die talespreek is een van die genadegawes uit 'n groot verskeidenheid wat deur die Gees gegee word.

Daar is 'n verskeidenheid van genadegawes, maar dit is dieselfde Gees wat dit gee (I Kor 12:4)

Aan nog een gee $\mathrm{Hy}$ die vermoë om allerhande tale te praat (I Kor 12:10).

Hierdie taal wat as werking van die Gees deur sommiges gepraat word, is ' $n$ taal van 'n eie aard. Dis nie 'n onbekende bestaande taal nie wat 'n mens sou kon leer nie, maar ' $n$ taal wat die spreker of iemand anders alleen kan verstaan deur nog ' $n$ gawe van die Gees. Paulus vergelyk hierdie spreke met lewelose instrumente soos 'n fluit 
of ' $n$ harp. As daar nie klank en toonverskille is nie, sal 'n mens nie weet wat gespeel word nie. Hieruit kan die afleiding miskien geregverdig wees dat 'n mens hier te doen het met 'n uitspreek van los woorde en die uitbring van ongeartikuleerde klanke wat die indruk gee dat daar in ' $n$ vreemde taal gepraat word. Dis in elk geval duidelik dat ons met ' $n$ taal te doen het wat nie die kenmerke van 'n gewone menslike taal besit nie en daarom vir die gewone mens onverstaanbaar.

Iemand wat in ' $n$ taal praat, rig hom nie tot die medemens nie, maar tot homself en tot God.

As daar nie iemand is wat dit kan uitlê nie, moet die talespreker in die byeenkoms van die gemeente stilbly en net tuis met homself en met God praat (I Kor 14:28).

Wat die spreke tot God betref, dra dit 'n gebedskarakter en is dit ook ' $n$ vorm waarin lof aan God toegebring word. Hierdie soort gebed is egter van so 'n aard dat die verstand nie daarby betrokke is nie, en skynbaar is dit ook die geval met die lof,

Want as ek in 'n taal bid, dan bid my gees, maar my verstand is onvrugbaar (I Kor 14:14).

Ek moet met die gees die lof van die Here sing, maar ek moet dit ook met die verstand doen (I Kor 14:15).

Hierdie spreek sonder dat die verstand daarby betrokke is, sou 'n mens 'n onpersoonlike, objektiewe wyse van spreek kon noem wat die vermoede versterk dat ' $n$ mens hier met ekstatiese spreke te doen het.

As die apostel in I Korintiërs 12:10, 28 praat van die vermoë wat aan sommiges gegee is om in allerhande tale te praat, wil dit voorkom asof daar opening gelaat moet word vir die moontlikheid van verskillende charismatiese tale. Die apostel self praat van tale van mense en van engele (I Kor 13:1). Daar is Nuwe Testamentici wat reken dat die taal wat as nuut of vreemd aangedui word, die paradystaal is.

Die belangrikste in verband met hierdie genadegawe is nie die feit van sy daarwees nie, maar die betekenis wat die apostel daaraan heg. Dis baie duidelik, veral uit I Korintiërs 14, dat die betekenis van hierdie genadegawe vir die gemeente uiters gering is. Hoewel die apostel beveel dat die praat in tale nie verhinder moet word nie, en hoewel hy daarop roem dat hy meer in tale praat as al die Korintiërs, ken hy tog in die gemeente ' $n$ baie geringe betekenis daaraan toe. Vir die gemeente geld een norm, en dit is die bedoeling van die Gees met die verlening van genadegawes, dat dit tot nut van die gemeente, tot opbouing van die gemeente aangewend moet word. Die opbouing van die gemeente geskied egter deur die spreek van duidelike en 
verstaanbare woorde. Daarom is daar in die gemeente slegs plek vir talespreek as dit ook uitgelê kan word. Is dit nie moontlik nie, moet iemand wat hierdie gawe ontvang het, dit verantwoordelik volgens die bepaling van die liefde gebruik, dit wil sê hy moet in die gemeente stilbly en tuis, in sy eie persoonlike godsdiensoefening tot sy eie stigting spreek. Veel hoër as die gawe van talespreek, is die gawe van die profesie, en die strewe van die gemeente moet in hierdie rigting wees. Talespreek is vir die gemeente, vir die uitbreiding van die evangelie in die wêreld volgens die apostel nutteloos.

Die skerpste uitspraak oor die kwaliteit van die talespreek by die Korintiërs het ons in die vermelding dat die spreek in tale ' $n$ teken vir die ongelowiges is en nie vir die gelowiges nie. Talespreek is ' $n$ teken van wonder-, bonatuurlike krag. As goddelike teken, word dit gewoonlik nie verstaan nie, soos die teken van Jona (Matt 12:39). Lietzmann (An die Korinther, s 73) reken dat Paulus die talespreek in hierdie bepaalde teks bloot as ' $n$ wonderteken sien wat God in die wêreld gestuur het sodat die ongelowiges hulle daaraan sou erg wat hulle dan as skuld toegereken sal word. Vir die ongelowige is dit 'n teken van oordeel en skuld. Hierteenoor staan die profesie wat ' $n$ teken van genade in Christus is. In hierdie verband is die eerste verse van I Korintiërs 12 ook belangrik waar Paulus begin met sy onderrig oor die geestesgawes. Dat 'n mens begeesterd kan wees (pneumaties) is op sigself nie die belangrikste nie. Dit hang daarvan af deur watter gees 'n mens besiel word. Toe die Korintiërs nog heidene was, is hulle deur 'n demoniese gees besiel en weggevoer na valse afgode. Deur hierdie gees het hulle toe gespreek. Maar as iemand deur die Gees van God besiel is, spreek hy duidelik, hy bely, en die inhoud van sy spreke en belydenis is: Jesus Christus. Die kwaliteit van die besieling(geestelikheid) blyk nie uit die feit van die spreek in tale nie, maar uit die inhoud. Die feit van die spreke is ' $n$ algemene verskynsel, en nie beperk tot Christene nie. Behm (ThWBzNT 719v v) is myns insiens reg as hy beweer dat Paulus ' $n$ uiterlike verwantskap tussen misties-ekstatiese verskynsels in die Hellenisme, soos talespreek, en in die vroeë Christendom erken. ' $n$ Mens sal die ekstatiese verskynsels, soos dit tot uiting kom in talepreek, in die godsdiensgeskiedenis ook verder as die Hellenisme kan aantoon.

So wys Van der Leeuw in sy Phänomenologie op die Griekse herkoms van die profeet: oorspronklik was hy die verteller van die kultuslegendes by die verskillende feeste. In verreweg die meeste gevalle word hierdie profeteamp ekstaties ervaar. Dit bring by die profeet 'n soort persoonlikheidsplitsing mee, 'n soort besetenheid wat die persoonlike, veral in die ervaring en denke, uitsluit. Hy kry die mag en vermoë om objektief te spreek sonder subjektiewe betrokkenheid daarby. Hierdie spreke is wesenlik onverstaanbaar en moet 
geïnterpreteer word. Die interpreteerders is deur die Grieke teoloë genoem.

Dieselfde moment van onverstaanbare spreke is blykbaar ook aanwesig by die ekstatiese profete van die $\mathrm{Ou}$ Testament. Ons verwys hier na die salwing van Jehu deur die profeteseun wat deur Elisa daartoe opgedra is. Nadat laasgenoemde vertrek het, vra die soldate vir Jehu: Waarom het hierdie kranksinnige by u gekom? En hy antwoord hulle: Julle self ken die man en sy gepraat (II Kon 9:11).

Die godsdiensgeskiedenis lewer oorvloedige getuienis dat ekstase uitbreek in wat die Duitsers "lallen"gestamel, 'n soort senuweeagtige "geluidvoortbring", noem. Dit gaan hier om 'n "spreke" waaroor die spreker nie mag het nie. "Die talespreker praat sonder dat hy wil, in baie gevalle skyn hy hom gedronge te voel om te spreek, in ander is dit miskien nie die geval nie: hy spreek soos 'n masjien, of beter, daar word uit hom gepraat. Die inhoud van wat hy praat, ken hy nie voordat hy praat nie, maar hy vat sy woorde op en verstaan hulle agterna as die woorde van iemand anders" (Österreich, Einführung in die Religionspsychologie, 1917 - v/d Leeuw, Phän s408).

\section{Nadere bepaling van die Lukas-gegewens}

Die pinkstergebeure volgens die berig van Lukas in Handelinge 2, val formeel binne die kader van wat Paulus die spreek in tale noem. Daar is egter tussen die spreek in tale by Paulus en die spreek in ander tale by Lukas hierdie verskil, dat volgens Handelinge 2 die dissipels se ander tale tog verstaanbare, bestaande tale was. Handelinge $10: 44 v \mathrm{v}$, waar daar in tale gespreek is, soos in Korinte, wil hierdie feit tog in verband bring met die pinkstergebeure, waardeur daar weer verband veronderstel moet word tussen die spreek in tale en die spreek in ander tale. Dat die ekstatiese ook by die dissipels nie ontbreek nie, wil Behm terugvind in die smalende opmerking van party wat sê: Hulle is dronk. So 'n spreke is soos iemand wat buite sy bewussyn praat. Die vraag is ook of elkeen van die dissipels in die verskillende tale gepraat het, dan moes dit deurmekaarpratery gewees het en onverstaanbaar, want as elkeen verstaanbaar gepraat het, waarom spot party dan. Behm dink aan twee bronne wat in Handelinge 2 saamgevoeg is:

Die historiese kern in die verhaal is 'n ekstatiese ervaring van die teenwoordigheid van die Heilige Gees in die oergemeente wat baie gou oorgaan in die profetiese getuienis van Petrus en lei tot missionêre handeling. Die pinksterverhaal van Lukas is ' $n$ legendariese voortbou van eersgenoemde waarin paralelle tussen die ontstaan van die Joodse gemeente - met die wetgewing te Sinaï - en die ontstaan van die Christendom as wêreldgodsdiens 'n belangrike rol spreel. Volgens rabbynse berigte het Gods Woord hom in 70 tale verdeel 
sodat elke volk die wet in sy eie taal kon verneem. Hiermee stem die taalwonder van die evangelie ooreen in Handelinge 2.

Die verskil tussen die Pauliniese en Lukaanse gegewens oor die talespreek kan kortliks so opgesom word:

- In Handelinge word vermeld dat verskillende groepe - in Jerusalem, Sesarea en Efese - in tale gespreek het toe die Gees op hulle gekom het. In Korinte was dit 'n gawe slegs aan enkeles.

- Talespreek was in Handelinge 'n aanvanklike en tydelike ervaring, terwyl dit in Korinte ' $n$ voortdurende gawe was, en onder kontrole van die spreker (I Kor 14:27, 28).

- In Jerusalem is die tale verstaan, in Korinte was 'n verdere gawe van uitleg nodig om dit te verstaan.

- Alleen in Handelinge is daar vermelding van ander tale.

\section{Konklusie}

Uit die voorgaande materiaal kan die volgende konkluderend gestel word:

Voorop moet gestel word dat daar geen duidelike uitspraak gemaak kan word oor die aard van die tongespraak nie. Ons het hier te doen met ' $n$ waarskynlik eenmalige, kortstondige verskynsel in die vroeë Christelike gemeente. Uit die Bybelse materiaal is daar egter voldoende gegewens wat ons in staat stel om enkele vasstellings te maak omtrent die wesenlike van die verskynsel wat ook dien om 'n mens te vrywaar van verkeerde of ongeoorloofde gevolgtrekkings te maak. Enkele van die vasstellings is die volgende:

Wat die Handelinge-mededeling betref, gaan dit waarskynlik om die volgende twee sake: die talespreek is ' $n$ versekeringsteken van die daadwerklike aanwesigheid van die Heilige Gees in die kerk (As die Gees uitgestort word, spreek die dissipels in ander tale. As Petrus twyfel omtrent die doop van heidene, kom die Gees op almal in die huis van Kornelius, die bewys is die spreek in tale. Waar die Gees is, is Christus en omgekeerd, daarom as hulle in Efese in die Naam van Jesus gedoop word en Paulus hulle die hande oplê, spreek hulle in tale - 'n teken van die aanwesigheid van die Gees).

Wat die betekenis van die talespreek in Handelinge betref, is dit duidelik dat dit geen gerigte spreke tot mense is nie, maar lofprysing en danksegging aan God. Dit gaan dus om 'n handeling tussen gelowige en God alleen.

Wat die Korinte gegewens betref, geld ook die voorafgaande opmerking van die Godgerigte lofprysing. Dis 'n saak tussen individuele gelowiges en God en het slegs betekenis vir die persoonlike godsdienstige lewe. Dis ' $n$ gawe van God, en daarom hoef 'n mens jou nie daarop teenoor ander te beroem nie, soos die Korintiërs graag 
wou doen om hulle "geestelikheid" te toon. As religieuse uiting gewerk deur die Heilige Gees, wil Paulus wel 'n plek daarvoor laat in die lewe van afsonderlike gelowiges. Hy self praat meer as almal in Korinte in tale. Wat hy hiermee bedoel, is nie duidelik nie. Wat wel baie duidelik is, is dat die apostel die talespreek in die gemeente glad nie hoog aanslaan nie. Daar is dit eintlik betekenisloos as dit nie verstaanbaar uitgelê word nie. Dis maar een van die geringere genadegawes. Dis baie beter om te strewe na die beste gawes, soos byvoorbeeld die profesie. Daarmee het hy alle geesdrywery en dwepery by die wortel afgesny.

Die talespreek van die Bybel is seker nie dieselfde as die ekstatiese "lallen", stamel, wat ons in die godsdiensgeskiedenis kry nie, maar dit vertoon wel trekke van ooreenkoms. Daarom sal 'n mens die verskynsel veral kry by ekstatiese, gevoelsmatige, emosioneel-geaarde mense en groepe, soos die geskiedenis ook reeds bewys het. 